\title{
EFISIENSI KERJA PEGAWAI DENGAN SISTEM INFORMASI BERBASIS KOMPUTER DI KANTOR DINAS PENDIDIKAN
}

\section{Listriyanti Palangda}

Universitas Negeri Manado, Indonesia

Email: listriyantipalangda@unima.ac.id

\section{Abstrak}

Latar belakang: Sistem informasi berbasis komputer untuk memproses data menjadi informasi yang memiliki arti, ada perbedaan yang cukup mendalam antara komputer dan program komputer di satu sisi dengan sistem informasi di sisi lainnya.

Tujuan penelitian: untuk mengetahui efisiensi kerja pegawai dengan sistem informasi berbasis komputer di kantor Dinas Pendidikan Kabupaten Tana Toraja

Metode penelitian: Penelitian ini merupakan penelitian kuantitatif. Populasi dalam penelitian ini berjumlah 54 orang dan semua populasi dijadikan sebagai sampel.

Hasil penelitian: Pengumpulan data dilakukan dengan menggunakan angket, observasi dan wawancara. Hasil penelitian adalah pegawai Dinas Pendidikan Kabupaten Tana Toraja sudah menunjukkan pengggunaan sistem informasi berbasis komputer yang baik dalam melaksnakan setiap tugas.

Kesimpulan:Pegawai Dinas Pendidikan Kabupaten Tana Toraja sudah mampu menggunakan komputer dalam mengerjakan berbagai pekerjaan kantor mulai dari mengumpulkan data, mengolah, memelihara dan output data

Kata kunci: Efisiensi Kerja Pegawai, Sistem Informasi Berbasis Komputer

\section{Abstract}

Background: Computer-based information systems to process data into meaningful information, there are quite deep differences between computers and computer programs on the one hand and information systems on the other.

The purpose of the study: to determine the work efficiency of employees with a computerbased information system at the Tana Toraja Regency Education Office.

Research method:This research is a quantitative research. The population in this study amounted to 54 people and all populations were used as samples.

The results of the study: Data collection was carried out using questionnaires, observations and interviews. The result of the research is that the employees of the Education Office of Tana Toraja Regency have shown good use of computer-based information systems in carrying out each task.

Conclusion: Employees of the Education Office of Tana Toraja Regency are able to use computers in doing various office work, starting from collecting data, processing, maintaining and outputting data.

Keywords: Employee Work Efficiency, Computer-Based Information System

Diterima: 25-12-2019 Direvisi: 5-01-2021 Disetujui: 6-01-2021

\section{PENDAHULUAN}

Perkembangan organisasi tidak terlepas dari peranan sumber daya manusia, sistem yang terbangun baik, aturan yang dinuat sedemikian rupa baik, tidak akan dapat memberikan hasil dan dampak yang positif jika tidak diikuti oleh kinerja sumber daya manusia (Handayani \& Rasyid, 2015). Organisasi merupakan sebuah sistem yang secara bersinergi dan bekerja bersama-sama untuk menghasilkan sesuatu tujuan, tentunya memerlukan sumber daya manusia yang handal, kreatif dan produktif (Budiwati, 2011). Untuk mewujudkan sistem yang baik, sebaiknya para pegawai dibekali dengan

\begin{tabular}{ll}
\hline & Listriyanti Palangda. (2021). Efisiensi Kerja Pegawai dengan Sistem Informasi Berbasis \\
& Komputer di Kantor Dinas Pendidikan. Co-Value: Jurnal Ekonomi, Koperasi Kewirausahaan \\
& Vol 12(1):7-15 \\
How to cite: & \\
\hline E-ISSN: & https://greenpublisher.id/ \\
\hline Published by: &
\end{tabular}


pengetahuan, pengalaman serta sarana dan prasarana yang mendukung penyelenggaraan dan pengelolaan administrasi yang efektif dan efisien (Irmayanti et al., 2019).

Dalam suatu kantor efisiensi kerja merupakan hal yang sangat penting, maka para pegawai perlu memahami segala persoalan yang berhubungan dengan efisiensi kerja, jika tidak maka dapat menimbulkan berbagai persoalan, misalkan jika pegawai mengerjakan sesuatu pekerjaan yang biasanya dapat diselesaikan dalam jangka waktu yang singkat maka pekerjaan itu akan selesai dalam jangka waktu yang lama karena mungkin dalam penyelesaiannya masih memakai cara yang lama, sehingga waktu banyak yang terbuang (Wijaya \& Rifa'i, 2016). Padahal jika pegawai mempergunakan teknologi yang canggih seperti komputer maka pekerjaan itu selesai dengan cepat.

Dengan menggunakan cara kerja yang sederhana, penggunaan alat yang dapat membantu mempercepat penyelesaian tugas serta menghemat tenaga, materi dan waktu, maka seseorang dikatakan bekerja dengan efisien dan memperoleh hasil yang memuaskan (Anggraeni \& Martoatmodjo, 2015). Tujuan utama pekerjaan kantor adalah untuk mencapai efisiensi kerja (Atmaja et al., 2018). Dalam pelaksanaan suatu pekerjaan sering dijumpai kendala- kendala yang dapat mempengaruhi kelancaran aktivitas kerja. Diantaranya dapat berupa sistem, prosedur atau cara kerja yang kurang efisien dalam melaksanakan tugas (Silvana \& Fajrin, 2015). Banyak kantor yang memiliki modal dan tenaga kerja yang lengkap tetapi tidak dapat mencapai tujuan yang telah ditentukan sebelumnya. Hal ini dapat terjadi karena karena kurang baiknya pelaksanaan penerapan tata kerja pada kantor tersebut. Dan dipengaruhi oleh sistem yang digunakan masih bersifat tradisional dalam pengolahan suatu data.

Efisiensi kerja dapat tercapai jika pengolahan informasi menggunakan sistem yang moderen, salah satu sistem informasi yang moderen sekarang ini adalah sistem informasi berbasis computer (Adisel, 2019). Harapan yang ingin diperoleh dalam sistem informasi tersebut adalah bahwa dengan menggunakan teknologi informasi berbasis komputer, informasi yang dihasilkan dapat lebih berkualitas, akurat dan tepat waktu. Sistem informasi merupakan suatu sistem berbasis komputer yang menyediakan informasi bagi beberapa pemakai dengan kebutuhan yang serupa (Sudjiman \& Sudjiman, 2018). Para pemakai biasanya tergabung dalam suatu entitas organisasi formal, seperti Dinas Pendidikan. Informasi menjelaskan mengenai organisasi atau salah satu sistem utamanya mengenai apa yang telah terjadi pada masa lalu, apa yang sedang terjadi sekarang dan yang mungkin akan terjadi dimasa yang akan datang tentang organisasi tersebut (Sitompul, 2016).

Teknologi informasi, termasuk sistem informasi berbasis komputer, memainkan peranan penting (Sudjiman \& Sudjiman, 2018). Sistem informasi adalah sekumpulan hardware, software, brainware, prosedur, dan atau yang diorganisasikan secara integral untuk mengolah data menjadi informasi yang bermanfaat guna memecahkan masalah. Data merupakan fakta-fakta yang mewakili suatu keadaan, kondisi, atau peristiwa yag terjadi atau ada dalam lingkungan fisik organisasi.

Sistem informasi berbasis komputer untuk memproses data menjadi informasi yang memiliki arti, ada perbedaan yang cukup mendalam antara komputer dan program komputer di satu sisi dengan sistem informasi di sisi lainnya (Rahmawati, 2015). Komputer dan perangkat lunak komputer yang tersedia merupakan fondasi teknis, alat dan material dari sistem informasi moderen. Komputer dapat dipakai untuk menyimpan dan memproses informasi. Program komputer atau perangkat lunak komputer merupakan seperangkat instruksi operasi yang mengarahkan dan mengendalikan pemrosesan informasi (Irham et al., 2021).

Berdasarkan hasil observasi (25 November 2021) terlihat bahwa efisiensi kerja di Kantor Dinas Pendidikan Kabupaten Tana Toraja dipengaruhi oleh sistem informasi 
berbasis komputer, hal ini dapat dilihat dari masih banyaknya pegawai yang masih menggunakan sistem manual dalam mengolah data sehingga membutuhkan waktu yang agak lama. Berdasarkan uraian tersebut peneliti termotivasi untuk mengkaji mengenai "Efisiensi Kerja Pegawai dengan Sistem Informasi Berbasis Komputer di kantor Dinas Pendidikan Kabupaten Tana Toraja".

\section{METODE PENELITIAN}

Penelitian ini hanya mengkaji satu variabel yaitu variabel efisiensi kerja pegawai dengan sistem informasi berbasis komputer, yang biasanya disebut variabel tunggal, yaitu variabel yang tidak mengkaji interaksi ataupun hubungan antar variabel.

\section{HASIL DAN PEMBAHASAN}

Penyajian data hasil penelitian merupakan gambaran mengenai distribusi jawaban responden terhadap angket yang diberikan, sehingga dari jawaban tersebut dapat diketahui tanggapan responden terhadap variabel dan indikator efisiensi kerja Pegawai Dinas Pendidikan Kabupaten Tana Toraja. Penyajian dan pengolahan data diuraikan secara sistematis berdasarkan indikator penelitian sebagai berikut:

\section{Mengumpulkan Data}

Dalam mengumpulkan data ada beberapa hal yang perlu diperhatikan adalah pikiran, tenaga, waktu, benda dan ruang.

Tabel 1.Distribusi Frekuensi dan Persentase Mengumpulkan Data dengan Komputer oleh Pegawai Dinas Pendidikan Kabupaten Tana Toraja.

\begin{tabular}{cccc}
\hline Interval kelas & Kategori & Frekuensi & Persentase(\%) \\
\hline $21-24$ & Sangat Efisien & 13 & 24,08 \\
$17-20$ & Efisien & 21 & 38,89 \\
$13-16$ & Cukup Efisien & 10 & 18,52 \\
$9-12$ & Kurang Efisien & 8 & 14,81 \\
$5-8$ & Tidak Efisien & 2 & 3,70 \\
\hline Jumlah & $\mathbf{5 4}$ & $\mathbf{1 0 0}$ \\
\hline
\end{tabular}

Berdasarkan hasil pengolahan Data dengan menggunakan SPSS, dapat diketahui bahwa rata-rata (mean) dari data pada tabel di atas adalah 18, 35. Berdasarkan tabel tersebut dapat diketahui bahwa jumlah responden yang menjawab di atas rata-rata lebih besar daripada responden yang menjawab di bawah rata-rata. Hal tersebut menandakan bahwa mayoritas responden menyatakan bahwa dalam mengumpulkan data dibutuhkan komputer.

Hasil analisis deskriptif terhadap jawaban responden menunjukkan bahwa selama ini pegawai Dinas Pendidikan Kabupaten Tana Toraja dalam mengumpulkan data sudah mengggunakan komputer. Mereka tidak lagi menggunakan cara manual yang jika cara ini digunakan akan menguras pikiran, tenaga, dan waktu yang lama. Perkembangan jaman sangat bermanfaat dan akan membawa perubahan-perubahan yang signifikan dari tahun ke tahun.

Berdasarkan hasil wawancara dengan KASI TENDIK Pendidikan Kabupaten Tana Toraja, Bapak Drs. Benyamin Perdi P. MM mengemukakan bahwa:

Tanpa komputer, mengumpulkan data adalah pekerjaan yang sangat susah, dimana pegawai harus menyediakan kertas kerja sebagai media untuk mencatat informasiinformasi (SETIAJI, 2020). Namun dengan adanya komputer pegawai sudah gampang 
mengumpulkan data dalam bentuk file. Saya sangat menginginkan teman-teman pegawai untuk bisa mempergunakan komputer dala mengerjakan berbagai macam pekerjaan.

Hasil pengamatan selama berlangsung penelitian, memang sangat terlihat jelas bahwa sebagaian besar pegawai Dinas Pendidikan Kabupaten Tana Toraja sudah menggunakan komputer dalam bekerja (As, 2019). Dari hasil analisis data yang dirumuskan pada lampiran 7, maka dapat disimpulkan bahwa dalam mengumpulkan data dengan komputer menunjukkan kategori efisien dengan hasil yang diperoleh sebesar 73,40 persen yang berada pada rentang nilai $61 \%-80 \%$.

\section{Mengolah Data}

Dalam rangka pengopersian komputer dalam menunjang pelaksanaan tugas sistem informasi dalam suatu instansi, maka operator komputer harus betul-betul menguasai bahasa komputer dan operasi sistem itu sendiri sehingga dapat digunakan untuk mengolah data (RA DWI AYU, 2021). Mengolah data adalah salah satu sistem kerja yang dapat dilakukan oleh perangkat elektronik yang terdapat pada komputer. Tahap dalam pengolahan data yaitu pengakumulasian atau perhitungan dan perbandingan antara dua tau lebih golongan data. Untuk mengetahui apakah pegawai Dinas Pendidikan Kabupaten Tana Toraja menggunkan komputer dalam mengolah data, maka dilakukan dengan metode angket dengan jumlah pertanyaan 5 item yang disebar ke seluruh pegawai Dinas Pendidikan Kabupaten Tana Toraja.

Tabel 2. Distribusi Frekuensi dan Persentase Mengolah Data dengan Komputer oleh Pegawai Dinas Pendidikan Kabupaten Tana Toraja.

\begin{tabular}{clcc}
\hline Interval kelas & Kategori & Frekuensi & Persentase(\%) \\
\hline $21-24$ & Sangat Efisien & 3 & 5,56 \\
$17-20$ & Efisien & 24 & 44,44 \\
$13-16$ & Cukup Efisien & 19 & 35,19 \\
$9-12$ & Kurang Efisien & 7 & 12,96 \\
$5-8$ & Tidak Efisien & 1 & 1,85 \\
\hline & Jumlah & $\mathbf{5 4}$ & $\mathbf{1 0 0}$ \\
\hline
\end{tabular}

Berdasarkan hasil pengolahan data dengan menggunakan SPSS, dapat dikatahui bahwa rata-rata (mean) dari data pada tabel di atas adalah 17,75 persen. Berdasarkan tabel tersebut dapat diketahui bahwa jumlah responden yang menjawab di atas rata-rata lebih besar daripada jumlah responden yang menjawab di bawah rata-rata. Hal tersebut menandakan bahwa mayoritas responden menyatakan bahwa dalam mengolah data sangat dibutuhkan adanya komputer untuk mencapai efisiensi kerja.

Hasil analisis deskriptif terhadap jawaban responden menunjukkan bahwa dalam mengolah data dengan menggunakan komputer sudah efisien karena dengan menggunakan komputer data yang jumlahnya banyak dapat diselesaikan dengan cepat dan tepat oleh pegawai Dinas Pendidikan Kabupaten Tana Toraja, dibandingkan dengan sistem manual yang membutuhkan waktu yang lama, dan sering menemui kendalakendala, seperti salah hitung dan lain sebagainya.

Berdasarkan hasil wawancara dengan KASI TENDIK Pendidikan Kabupaten Tana Toraja, Bapak Drs. Benyamin Perdi P. MM mengemukakan bahwa:

Komputer, sangat membantu dalam pengolahan data khususnya dalam perhitungan. Sebagai manusia yang terbatas seringkali perhitungan yang kita lakukan salah hitung, sehingga dengan adanya komputer kesalahan perhitungan bisa diminimalisir.

Dari uraian di atas, dapat disimpulkan bahwa komputer sangat membantu dalam setiap pekerjaan yang dilakukan oleh pegawai. Sehingga dapat mencapai efisiensi kerja pegawai yang tinggi. Komputer dapat melakukan perhitungan. Dari hasil analisis data 
yang dirumuskan pada lampiran 8 , maka dapat disimpulkan bahwa dalam mengolah data dengan komputer menunjukkan kategori efisien dengan hasil yang diperoleh sebesar 71,03 persen yang berada pada rentang nilai $61 \%-80 \%$.

\section{Memelihara Data}

Memelihara data meliputi penyimpanan data dengan menggunakan sistem abjad, nomor, subjek dan lain- lain dengan tujuan agar cepat ditemukan dan perlindungan data yang disimpan agar tidak rusak atau hilang. Untuk mengetahui apakah pegawai Dinas Pendidikan Kabupaten Tana Toraja menggunkan komputer dalam memelihara data, maka dilakukan dengan metode angket dengan jumlah pertanyaan 5 item yang disebar ke seluruh pegawai Dinas Pendidikan Kabupaten Tana Toraja.

Tabel 3. Distribusi Frekuensi dan Persentase memelihara Data oleh Pegawai Dinas Pendidikan Kabupaten Tana Toraja.

\begin{tabular}{clcc}
\hline Interval kelas & Kategori & Frekuensi & Persentase $(\%)$ \\
\hline $21-24$ & Sangat Efisien & 3 & 5,56 \\
$17-20$ & Efisien & 24 & 44,44 \\
$13-16$ & Cukup Efisien & 19 & 35,19 \\
$9-12$ & Kurang Efisien & 7 & 12,96 \\
$5-8$ & Tidak Efisien & 1 & 1,85 \\
\hline & Jumlah & $\mathbf{5 4}$ & $\mathbf{1 0 0}$ \\
\hline
\end{tabular}

Berdasarkan hasil pengolahan data dengan menggunakan SPSS, dapat dikatahui bahwa rata-rata (mean) dari data pada tabel di atas adalah17,75 persen. Berdasarkan tabel tersebut dapat diketahui bahwa jumlah responden yang menjawab di atas rata-rata lebih besar daripada jumlah responden yang menjawab di bawah rata-rata. Hal tersebut menandakan bahwa mayoritas responden menyatakan bahwa dalam mengolah data dibutuhkan komputer.

Hasil analisis deskriptif terhadap jawaban responden menunjukkan bahwa untuk memelihara data dengan baik perlu membutuhkan komputer. Data yang tersimpan dalam komputer akan mudah ditemukan apabila dicari, dan tidak akan rusak.

Berdasarkan hasil wawancara dengan KASI TENDIK Pendidikan Kabupaten Tana Toraja, Bapak Drs. Benyamin Perdi P. MM mengemukakan bahwa:

Dalam hal memelihara data- data Dinas Pendidikan Kabupaten Tana Toraja pegawai sudah menyimpan dalam komputer karena sewaktu-waktu data itu dibutuhkan. Pegawai dalam memelihara data tidak akan susah menata data-data penting di dalam lemari atau tempat penyimpanan data.

Dari hasil wawancara di atas, dapat disimpulkan bahwa pegawai Dinas Pendidikan Kabupaten Tana Toraja dalam memelihara data dilakukan dengan cara disimpan didalam komputer, dengan tujuan agar cepat ditemukan, dan memudahkan pegawai dalam mencari data jika dibutuhkan. Dari hasil analisis data dapat disimpulkan bahwa dalam mengolah data dengan komputer menunjukkan kategori efisien dengan hasil yang diperoleh sebesar 70,59 persen yang berada pada rentang nilai $61 \%-80 \%$.

\section{Output Data}

Tahap ini meliputi pembuatan laporan yang merupakan penyajian formal dan distribusi data/ informasi yang diolah yang dapat diprint sehingga menjadi suatu dokumen-dokumen yang bermanfaat dan dapat digunakan oleh Dinas Pendidikan Kabupaten Tana Toraja jika dibutuhkan seperti pembuatan laporan pertanggungjawaban program-program yang sudah dilaksanakan, document melaksanakan monitoring 
terhadap pelaksanaan program/kegiatan dinas serta menyiapkan tindak lanjut hasil monitoring. Untuk mengetahui apakah pegawai Dinas Pendidikan Kabupaten Tana Toraja menggunakan komputer dalam output data (keluaran data), maka dilakukan dengan metode angket dengan jumlah pertanyaan 5 item yang masing-masing indikator yaitu, pikiran, tenaga, waktu, ruang dan benda yang disebar ke seluruh pegawai Dinas Pendidikan Kabupaten Tana Toraja yang berjumlah 54 orang termasuk Kepala Dinas.

Tabel 4. Distribusi Frekuensi dan Persentase output Data oleh Pegawai Dinas Pendidikan Kabupaten Tana Toraja.

\begin{tabular}{clcc}
\hline Interval kelas & Kategori & Frekuensi & Persentase $(\%)$ \\
\hline $21-24$ & Sangat Efisien & 3 & 5,56 \\
$17-20$ & Efisien & 24 & 44,44 \\
$13-16$ & Cukup Efisien & 19 & 35,19 \\
$9-12$ & Kurang Efisien & 7 & 12,96 \\
$5-8$ & Tidak Efisien & 1 & 1,85 \\
\hline & Jumlah & $\mathbf{5 4}$ & $\mathbf{1 0 0}$ \\
\hline
\end{tabular}

\section{Sumber Data: Hasil Olahan Angket No. 5}

Berdasarkan hasil pengolahan data dengan menggunakan SPSS, dapat dikatahui bahwa rata-rata (mean) dari data pada tabel di atas adalah 17,09 persen. Berdasarkan tabel tersebut dapat diketahui bahwa jumlah responden yang menjawab di atas rata-rata lebih besar daripada jumlah responden yang menjawab di bawah rata-rata. Hal tersebut menandakan bahwa mayoritas responden menyatakan bahwa dalam output data dibutuhkan komputer.

Hasil analisis deskriptif terhadap jawaban responden menunjukkan bahwa pegawai Dinas Pendidikan Kabupaten Tana Toraja dalam output data atau pengeluaran data menggunakan komputer. Komputer akan memudahakan pegawai dalam melakukan segala pekerjaan kantor, contohnya dalam keluaran data, dengan menggunakan komputer maka data-data yang sudah tersimpan apabila diperlukan tinggal di print ataudo copy ke FD.

Berdasarkan hasil wawancara dengan KASI TENDIK Pendidikan Kabupaten Tana Toraja, Bapak Drs. Benyamin Perdi P. MM. mengemukakan bahwa:

Pegawai Dinas Pendidikan Kabupaten Tana Toraja soal output data telah mengguakan komputer. Data-data yang tersimpan dalam komputer apabila dibutuhkan, pegawai tinggal cari file tersebut dan print, sehingga tidak membutuhkan waktu yang banyak.

Dari hasil penyajian data terhadap keseluruhan indikator sistem informasi berbasis komputer, maka dapat diketahui bahwa dalam melakukan setiap pekerjaan kantor mulai dari mengumpulkan data, menghaluskan data, mengolah data, memelihara data dan output data, pegawai menggunakan komputer. Komputer sangat membantu pegawai dalam memudahkan pekerjaan mereka. Dari hasil analisis data yang dirumuskan pada lampiran 8, maka dapat disimpulkan bahwa dalam mengolah data dengan komputer menunjukkan kategori efisien dengan hasil yang diperoleh sebesar 68,37 persen yang berada pada rentang nilai $61 \%-80 \%$.

\section{Analisis Data}

Untuk mengetahui tingkat efisiensi kerja pegawai dengan sistem informasi berbasis komputer di Dinas Pendidikan Kabupaten Tana Toraja, maka dilakukan perhitungan jumlah skor terhadap keseluruhan indikator sistem informasi berbasis komputer yaitu mengumpulkan data, mengolah, memelihara dan output data dilihat dari segi efesiensi kerja yang meliputi pikiran, tenaga, waktu, benda dan ruang yang diajukan. 
Perhitungan jumlah skor tersebut dilakukan dengan menggunakan SPSS untuk kemudian di analisis secara deskriptif. Hasil perhitungan tersebut terlihat pada tabel di bawah ini:

Tabel 5 Distribusi Frekuensi dan Persentase efisiensi kerja Pegawai dengan Sistem Informasi Berbasis Komputer di Dinas Pendidikan Kabupaten Tana Toraja.

\begin{tabular}{clcc}
\hline Interval kelas & Kategori & Frekuensi & Persentase $(\%)$ \\
\hline $105-124$ & Sangat Efisien & 2 & 3,71 \\
$85-104$ & Efisien & 33 & 61,11 \\
$65-84$ & Cukup Efisien & 16 & 29,62 \\
$45-64$ & Kurang Efisien & 3 & 5,56 \\
$25-44$ & Tidak Efisien & 0 & 0 \\
\hline & Jumlah & $\mathbf{5 4}$ & $\mathbf{1 0 0}$ \\
\hline
\end{tabular}

Berdasarkan hasil pengolahan data dengan menggunakan SPSS, dapat diketahui bahwa rata-rata(mean) dari tabel di atas adalah 88, 07. Berdasarkan tabel tersebut dapat diketahui bahwa jumlah responden yang menjawab di atas rata-rata lebih besar daripada jumlah responden yang menjawab di bawah rata-rata. Hal tersebut menandakan bahwa efisiensi kerja pegawai dengan sistem informasi berbasis komputer di Dinas Pendidikan Kabupaten Tana Toraja dalam kategori sangat efisien.

Berdasarkan hasil wawancara dengan KASI TENDIK Pendidikan Kabupaten Tana Toraja, Bapak Drs. Benyamin Perdi P. MM mengemukakan bahwa:

Efisiensi kerja pegawai dengan sistem informasi berbasis komputer ditentukan oleh kemampuan pegawai dalam melakukan berbagai pekerjaan dengan menggunakan alat bantu komputer. Efisiensi kerja pegawai dinilai tinggi, jika semua pegawai mampu mengubah pekerjaan mereka dengan waktu yang singat, pekerjaan cepat terselesaikan dan hasilnya sesuai yang diharapkan.

Dari uraian di atas, dapat disimpulkan bahwa pegawai harus mampu menggunakan alat bantu komputer dalam setiap pekerjaan kantor. Efisiensi kerja pegawai dengan sistem informasi berbasis komputer ditentukan oleh kemampuan pegawai dalam mengubah pekerjaan mereka menjadi pekerjaan yang tidak banyak menguras pikiran, diselesaikan dalam waktu yang singkat dengan menggunakan komputer, sehingga para pegawai mamapu melaksanakan segala tugas dan tanggung jawabnya dalam waktu yang singkat dan memberikan hasil yang maksimal.

\section{Pembahasan}

Dalam suatu organisasi, pegawai harus mampu mengubah pekerjaan mereka dengan bantuan komputer. Efisiensi kerja bisa dalam kategori tinggi, apabila pegawai tidak menguras pikiran yang banyak, tenaga dan waktu tidak terbuang sia-sia, ruangan bisa ditata sedemikian rupa agar perabotan kantor diletakkan dekat pegawai yang sering menggunakannya.

Mengingat pentingnya efisiensi kerja pegawai dengan sistem informasi berbasis komputer, maka pegawai dalam bekerja mulai dari mengumpulkan data, menghaluskan, mengolah, memelihara dan output data harus terampil dalam menggunakan komputer, sehingga dapat mencapai tujuan organisasi secara efisien dan efektif. Efisiensi kerja pegawai Dinas Pendidikan Kabupaten Tana Toraja dalam bekerja sudah mampu menggunakan komputer sehingga efisiensi kerja pegawai sudah dalam kategori sangat efisien.

Hasil analisis data menunjukkan bahwa efisiensi kerja pegawai dengan sistem informasi berbasis komputer di kantor Dinas Pendidikan Kabupaten Tana Toraja berada dalam kategori sangat efisien dilihat dari distribusi frekuensi dan persentase efisiensi 
kerja pegawai dengan sistem informasi berbasis komputer yang rata-rata (mean) menunjukkan angka 88,07 persen.

Hal ini berarti secara umum pegawai Dinas Pendidikan Kabupaten Tana Toraja sudah menunjukkan pengggunaan sistem informasi berbasis komputer yang baik dalam melaksnakan setiap tugas. Hal ini didukung oleh pendapat Widjajanto (2001: 21), yang menyatakan bahwa sistem informasi manajemen pada dasarnya selalu menggunakan teknologi pengolahan data elektronis, semakin besar volume pengolahan atau yang ditangani, maka penggunaan komputer sangat efisien.

Umur responden yang masih tergolong produktif sudah sangat mahir mengoperasikan komputer dibandingkan dengan umur yang sudah 55 tahun keatas, hal ini disebabkan oleh daya ingat usia produktif masih tinggi dibandingkan usia 55 keatas, sehingga usia produktif masih sangat memungkinkan untuk ditingkatkan produktivitas kerjanya.

Pegawai Dinas Pendidikan Kabupaten Tana Toraja berada dalam kategori tahap perkembangan karir, hal ini dapat dilihat dari banyaknya pegawai yang sudah mencapai golongan III, yang menandakan bahwa pegawai tersebut memiliki tingkat pendidikan sarjana, yang dianggap cakap dalam mengoperasikan komputer dan memiliki kemampuan berpikir yang tinggi.

Pendidikan diyakini berpengaruh dalam meningkatkan keterampilan pegawai dalam mengoperasikan komputer, dimana pegawai Dinas Pendidikan Kabupaten Tana Toraja rata-rata SI. Semakin tinggi pendidikan seseorang semakin tinggi pula daya analisa seseorang dalam menyelesaikan masalah dan semakin tinggi penguasaan teknologinya khususnya dalam menggunakan komputer untuk bekerja.

Berdasarkan penjelasan di atas, dapat dinyatakan bahwa sangat efisien atau tidaknya efiisensi kerja pegawai ditentukan oleh peralatan yang digunakan seperti halnya komputer. Oleh kerena itu seharusnya instanti/kantor, khususnya Dinas Pendidikan Kabupaten Tana Toraja perlu mengembangkan sistem informasi berbasis komputer guna efisiensi kerja bias tercapai dengan baik

\section{KESIMPULAN}

Pegawai Dinas Pendidikan Kabupaten Tana Toraja sudah mampu menggunakan komputer dalam mengerjakan berbagai pekerjaan kantor mulai dari mengumpulkan data, mengolah, memelihara dan output data. Efisiensi kerja pegawai Dinas Pendidikan Kabupaten Tana Toraja dalam kategori sangat tinggi dilihat dari aspek pikiran, tenaga, waktu, ruang, dan benda.

\section{BIBLIOGRAFI}

Adisel, A. (2019). Manajemen Sistem Informasi Pembelajaran. Journal Of

Administration and Educational Management (ALIGNMENT), 2(2), 105-112.

Anggraeni, L. S., \& Martoatmodjo, S. (2015). Pengaruh Produktivitas, Efisiensi, Kepuasan Kerja Terhadap Perputaran Karyawan Bagian Marketing. Jurnal Ilmu Dan Riset Manajemen (JIRM), 4(5).

As, H. (2019). Pelayanan Publik Pendaftaran dan Penempatan Pencari Kerja Berbasis TIK Di Kota Makassar. Prosiding Seminar Nasional Universitas Indonesia Timur, l(1), 65-80. 
Atmaja, A. T., Santoso, D., \& Ninghardjanti, P. (2018). Penerapan Sistem Otomatisasi Admnistrasi Untuk Meningkatkan Efektivitas Dan Efisiensi Kerja Di Bidang Pendapatandinas Perdagangan Kota Surakarta. JIKAP (Jurnal Informasi Dan Komunikasi Administrasi Perkantoran), 2(2).

Budiwati, H. (2011). Dimensi Kepemimpinan Dan Motivasi Terhadap Kinerja Pegawai Koperasi Karyawan PT. Pindad Persero. Wiga: Jurnal Penelitian Ilmu Ekonomi, l(1), 49-55.

Handayani, T., \& Rasyid, A. A. (2015). Pengaruh kepemimpinan kepala sekolah, motivasi guru, dan budaya organisasi terhadap kinerja guru SMA negeri Wonosobo. Jurnal Akuntabilitas Manajemen Pendidikan, 3(2), 264-277.

Irham, I., Nurdin, N., \& Supriyadi, B. (2021). PEMANFAATAN ELEKTRONIK AUDIT (E-AUDIT) DALAM MENINGKATKAN KINERJA PEMERIKSA PADA AUDITORAT UTAMA KEUANGAN NEGARA VI BADAN PEMERIKSA KEUANGAN RI. Jurnal Inovasi Penelitian, 2(6), 1799-1812.

Irmayanti, E., Enas, E., \& Soedarmo, U. R. (2019). Analisis Pemberdayaan Aparatur Pemerintahan Daerah Dalam Rangka Meningkatkan Kinerja Pegawai Di Bappeda Kabupaten Pangandaran. Journal of Management Review, 3(3), 357-368.

RA DWI AYU, P. (2021). ANALISA SISTEM INFORMASI AKADEMIK (SISFO) DAN JARINGAN DI UNIVERSITAS BINA DARMA. ANALISA SISTEM INFORMASI AKADEMIK (SISFO) DAN JARINGAN DI UNIVERSITAS BINA DARMA.

Rahmawati, M. (2015). Peran Aplikasi Komputer Berbasis Akuntansi untuk Badan Usaha Dalam Persfektif Sistem Informasi. Jurnal Perspektif, 13(2), 171-183.

SETIAJI, A. B. (2020). PERANCANGAN SISTEM INFORMASI AKUNTANSI KEUANGAN DALAM MENINGKATKAN PENGENDALIAN INTERNAL PADA USAHA KECIL MENENGAH TAHU DUA SAUDARA TULUNGAGUNG.

Silvana, M., \& Fajrin, H. (2015). Analisis Proses Bisnis Sistem Pembuatan Surat Perintah Perjalanan Dinas Kantor Regional II PT. Pos Indonesia. Jurnal Nasional Teknologi Dan Sistem Informasi, 1(1), 18-22.

Sitompul, P. M. (2016). Penggunaan Sistem Informasi Manajemen (SIM) dalam Penyusunan Kebijakan Umum Anggaran (KUA) dan Prioritas Plafon Anggaran Sementara (PPAS) pada Badan Perencanaan Pembangunan Daerah Kota Medan.

Sudjiman, P. E., \& Sudjiman, L. S. (2018). Analisis sistem informasi manajemen berbasis komputer dalam proses pengambilan keputusan. TeIKa, 8(2), 55-66.

Wijaya, C., \& Rifa'i, M. (2016). Dasar-dasar manajemen: mengoptimalkan pengelolaan organisasi secara efektif dan efisien.

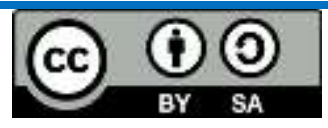

This work is licensed under a Creative Commons Attribution-ShareAlike 4.0 International License 